\title{
Effect of Elevated Temperature on Mechanical Properties of Limestone, Quartzite and Granite Concrete
}

\author{
Muhammad Tufail $^{1)}$, Khan Shahzada ${ }^{1)}$, Bora Gencturk $^{2), *}{ }^{(0}$, and Jianqiang Wei $^{2)}$
}

(Received April 3, 2016, Accepted October 11, 2016, Published online December 27, 2016)

\begin{abstract}
Although concrete is a noncombustible material, high temperatures such as those experienced during a fire have a negative effect on the mechanical properties. This paper studies the effect of elevated temperatures on the mechanical properties of limestone, quartzite and granite concrete. Samples from three different concrete mixes with limestone, quartzite and granite coarse aggregates were prepared. The test samples were subjected to temperatures ranging from 25 to $650{ }^{\circ} \mathrm{C}$ for a duration of $2 \mathrm{~h}$. Mechanical properties of concrete including the compressive and tensile strength, modulus of elasticity, and ultimate strain in compression were obtained. Effects of temperature on resistance to degradation, thermal expansion and phase compositions of the aggregates were investigated. The results indicated that the mechanical properties of concrete are largely affected from elevated temperatures and the type of coarse aggregate used. The compressive and split tensile strength, and modulus of elasticity decreased with increasing temperature, while the ultimate strain in compression increased. Concrete made of granite coarse aggregate showed higher mechanical properties at all temperatures, followed by quartzite and limestone concretes. In addition to decomposition of cement paste, the imparity in thermal expansion behavior between cement paste and aggregates, and degradation and phase decomposition (and/or transition) of aggregates under high temperature were considered as main factors impacting the mechanical properties of concrete. The novelty of this research stems from the fact that three different aggregate types are comparatively evaluated, mechanisms are systemically analyzed, and empirical relationships are established to predict the residual compressive and tensile strength, elastic modulus, and ultimate compressive strain for concretes subjected to high temperatures.
\end{abstract}

Keywords: concrete, fire resistance, limestone, quartzite, granite, mechanical properties.

\section{Introduction}

Concrete is the most widely used construction material in the world because of its durability, strength, and resistance to fire. Structural concrete must satisfy the fire safety requirements identified in building codes (EN 1992; ACI 2014). Although concrete, in general, has a high resistance to fire, its mechanical properties such as strength and elastic modulus decrease when subjected to high temperatures. The failure at elevated temperatures is mainly due to formation of cracks parallel to the heat surface, changes in the chemistry, and an increase in pore pressure as a results of evaporation of water (Gluekler 1979; Ali et al. 2004; Peng and Huang 2008). At high temperatures, various physical

\footnotetext{
${ }^{1)}$ Department of Civil Engineering, University of Engineering and Technology Peshawar, Peshawar, Pakistan.

${ }^{2}$ Sonny Astani Department of Civil and Environmental Engineering, University of Southern California, Los Angeles, CA, USA.

*Corresponding Author; E-mail: gencturk@usc.edu
}

Copyright $($ The Author(s) 2016. This article is published with open access at Springerlink.com (phase expansion, condensation, evaporation and vapor diffusion), chemical (thermo-chemical damage and dehydration) and mechanical (thermo-mechanical damage, spalling and cracking) phenomena take place in concrete that results in deterioration of its properties (Heikal 2000). As temperature is increased, the water on the surface of concrete and the capillary water is lost, and this process is accelerated by the reduced cohesive forces between water molecules due to water expansion (Hager 2013). At a temperature of $105^{\circ} \mathrm{C}$, the free water starts evaporating rapidly. In the temperature range from 80 to $150{ }^{\circ} \mathrm{C}$, dehydration of ettringite takes place followed by the decomposition of gypsum between 150 and $170{ }^{\circ} \mathrm{C}$ (Hager 2013). When the temperature reaches to $300{ }^{\circ} \mathrm{C}$, the chemically bound water starts to evaporate, which in turn decreases the compressive strength of concrete. As temperature is further increased, decomposition of portlandite occurs between 400 and $540{ }^{\circ} \mathrm{C}$. When temperature increases beyond $400{ }^{\circ} \mathrm{C}$, the concrete strength decreases more rapidly due to the degradation of calcium-silica-hydrate $(\mathrm{C}-\mathrm{S}-\mathrm{H})$. Second phase of the $\mathrm{C}-\mathrm{S}-\mathrm{H}$ decomposes in the temperature range from 600 to $800{ }^{\circ} \mathrm{C}$ forming $\beta-\mathrm{C}_{2} \mathrm{~S}$ (Hager 2013). At a temperature of $900{ }^{\circ} \mathrm{C}$, the $\mathrm{C}-\mathrm{S}-\mathrm{H}$ breaks down completely. Therefore, the critical temperature for concrete ranges from approximately 400 to $900{ }^{\circ} \mathrm{C}$. In this range concrete loses most of its strength. 
Aggregates normally occupy $50-75 \%$ of the volume in concrete, therefore, the behavior at elevated temperatures is strongly influenced by the type and properties of the aggregate used. Naturally found aggregates are usually stable up to 300 to $350{ }^{\circ} \mathrm{C}$. With regards to the high temperature properties of aggregates, thermal expansion and conductivity, and chemical and thermal stability are known to play an important role (Bentz 2007; Bentz et al. 2011). Abrams (1971) reported that carbonate and lightweight concretes exhibit similar strength characteristics at high temperatures and retain approximately $75 \%$ of their original strengths at $650{ }^{\circ} \mathrm{C}$, while siliceous concrete yield a lower strength, particularly above $430{ }^{\circ} \mathrm{C}$. It was also found that the original strength of the concrete has little influence on the percentage of residual strength at high temperatures. According to Sakr and El-Hakim (2005), the mechanical properties of concrete are inversely proportional to temperature, and among the heavy weight concretes for nuclear reactors containing gravel, barite and ilmenite aggregate, the ilmenite concrete, shows the highest density, modulus of elasticity, strength, and hence, it is the most resistant to high temperatures. Li and Liu (2016) investigated the tensile properties of hybrid fiber-reinforced concrete exposed to elevated temperatures from 20 to $900{ }^{\circ} \mathrm{C}$, and found that the basic reason for the degradation of mechanical properties of fiber-reinforced concrete is the deterioration of its microstructure by forming a number of pores in matrix and micro-cracks along the bonding interface between steel fibers and matrix. Arioz (2007) showed that the relative strength of concrete decreases as the exposure temperature increases from 200 to $1200{ }^{\circ} \mathrm{C}$, and the reduction is very sharp beyond $800{ }^{\circ} \mathrm{C}$. A more pronounced temperature dependence is observed in the case of river gravel aggregate in comparison to crushed limestone. Koksal et al. (2012) studied the physical and mechanical properties of four different concrete mixtures with varying amounts of expanded vermiculite (3-6\% by volume) subjected to temperatures ranging from 300 to $1100{ }^{\circ} \mathrm{C}$ for $6 \mathrm{~h}$. It was found that expanded vermiculate improves the high temperature stability of concrete significantly, by increasing the critical temperature for loss of strength to $900{ }^{\circ} \mathrm{C}$. Therefore, it was concluded that the expanded vermiculate could be a good alternative to other lightweight aggregates when high temperature resistance and low density are desired for concrete. There have also been studies on the effect of temperature on high strength and/or fiber-reinforced concrete with or without supplementary cementitious materials (Poon et al. 2001; Cheng et al. 2004; Savva et al. 2005; Husem 2006; Behnood and Ziari 2008; Behnood and Ghandehari 2009; Ghandehari et al. 2009). The literature review here is limited to those studies that investigated the effect of aggregate type on high temperature resistance of regular Portland cement concrete without supplementary cementitious materials for their relevance to the presented research.

The objective of this research is to systematically investigate the temperature dependency of mechanical properties of concrete containing different types of aggregates and to explore the corresponding mechanisms by considering phase transformation, decomposition, thermal expansion and deterioration of aggregates. The focus is placed on limestone, quartzite and granite coarse aggregates. It is expected that the results from this research will contribute to the existing knowledge by expanding the experimental database and providing empirical formulas to predict the residual mechanical properties of concretes containing different types of coarse aggregates subjected to high temperatures.

\section{Experimental Program}

\subsection{Materials}

The physical properties of the coarse aggregates, i.e., limestone, quartzite and granite, were determined according to pertinent standards [i.e., ASTM C-29 (2009), ASTM C-33 (2013), ASTM C-127 (2015) and ASTM C-566 (2013)] as shown in Table 1. Figure 1 shows pictures of coarse aggregates used in this study. As seen in Fig. 1, all the three aggregates were angular. Limestone had the lowest angularity, but quartzite exhibited smoother texture than the other two aggregates. Three different concretes were prepared, each one having one of these coarse aggregates. The fine aggregate was kept the same for all three concretes. The physical properties of the fine aggregate were also determined [according to ASTM C-70 (2013) and ASTM C-128 (2015)], and provided in Table 1. The particle size

Table 1 Physical properties of coarse and fine aggregates.

\begin{tabular}{c|c|c|c|c}
\hline \multirow{2}{*}{\begin{tabular}{c} 
Properties \\
\cline { 2 - 5 }
\end{tabular}} & Limestone & Quartzite & Granite & Fine aggregate \\
\hline \hline $\begin{array}{c}\text { Maximum size of aggregate } \\
(\mathrm{mm})\end{array}$ & 19 & 19 & 19 & n.a. \\
\hline Moisture content (\%) & 1 & 0.8 & 0.5 & 0.56 \\
\hline Water absorption (\%) & 1.95 & 1.87 & 1.78 & 1.79 \\
\hline Specific gravity & 2.42 & 2.64 & 2.68 & 2.65 \\
\hline Unit weight $\left(\mathrm{kg} / \mathrm{m}^{3}\right)$ & 1540.5 & 1655.7 & 1649.4 & n.a. \\
\hline Fineness modulus & n.a. & n.a. & n.a. & 2.65 \\
\hline
\end{tabular}

n.a. not applicable. 

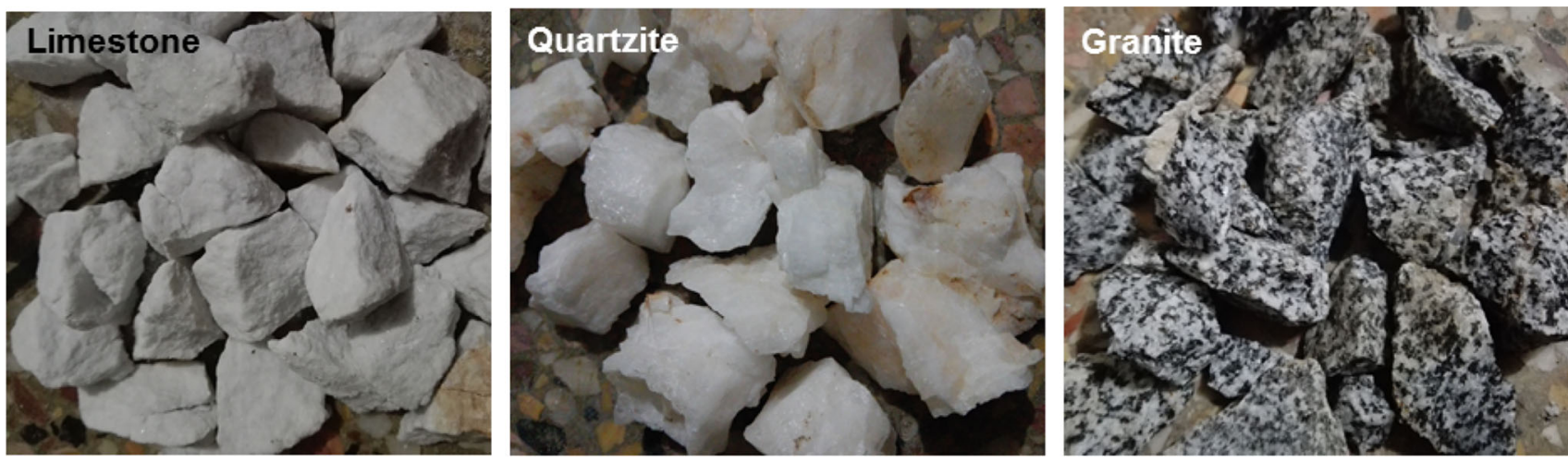

Fig. 1 Coarse aggregates.

(a)

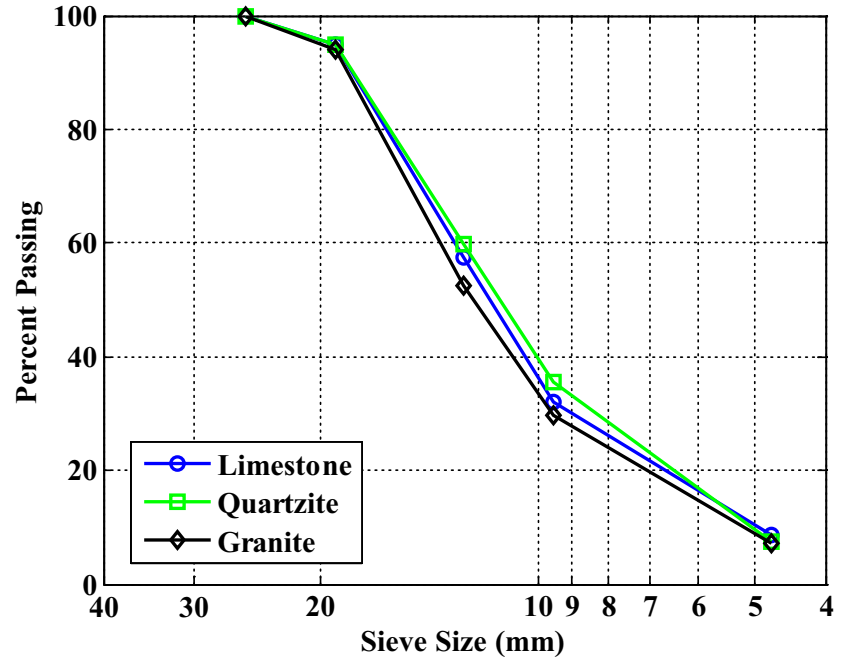

(b)

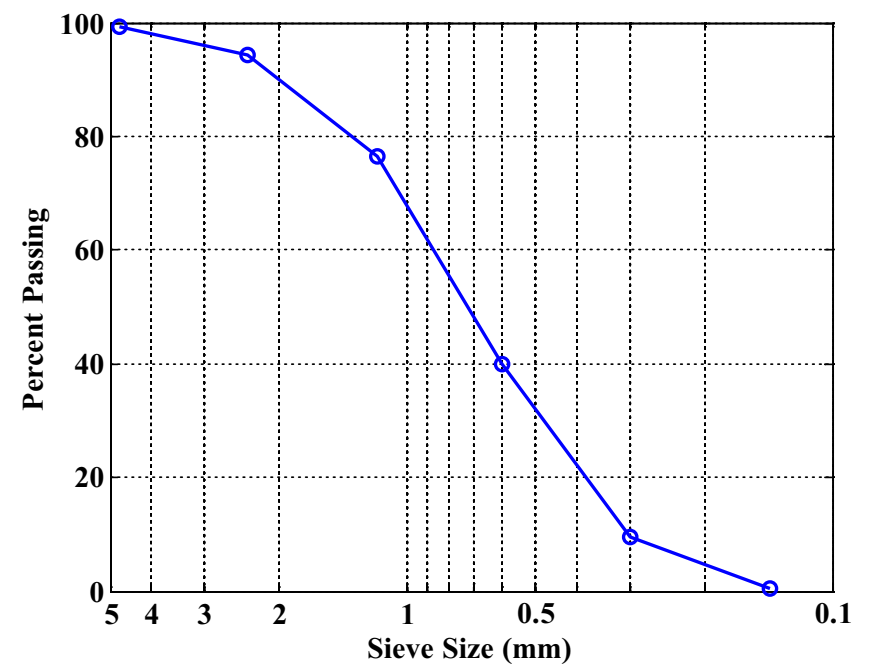

Fig. 2 Particle size distribution of a coarse and $\mathbf{b}$ fine aggregates.

distribution of the coarse and fine aggregates was determined [according to ASTM C-136 (2014)] as shown in Fig. 2a and $\mathrm{b}$, respectively. The chemical composition of the coarse aggregate was determined by X-ray fluorescence test, and the results are shown in Table 2.

\subsection{Sample Preparation}

The control mix (limestone concrete) was designed to yield a concrete strength of $21 \mathrm{MPa}$ at 28 days. A proportioning of 1:1.97:2.97 of cement, fine, and coarse aggregate, respectively, with a water-to-cement $(\mathrm{w} / \mathrm{c})$ ratio of 0.55 was determined. The aggregates were mixed in saturated surface dry condition. To ensure that there are only two factors that affect concrete mechanical properties, namely aggregate type and temperature, the same proportions as limestone concrete were used for the granite and quartzite concretes. The amounts of materials used in the control mix to obtain $1 \mathrm{~m}^{3}$ of concrete are shown in Table 3 (which were identical in proportion for the other concretes).

Forty-two concrete cylinder specimens, $150 \mathrm{~mm}$ in diameter and $300 \mathrm{~mm}$ in height, were cast from each mix (2 types of tests $\times 7$ temperatures $\times 3$ repetitions per testtemperature combination). The coefficient of variation of all the tests conducted on the same type of concrete at the same temperature and across all the temperature-concrete combinations were within $5 \%$. Compressive and split tensile strength tests were performed on the samples after being subjected to six different temperatures as described below. Samples from each mixture design were also tested as control (i.e., no temperature exposure). ASTM C-39 (2014) and ASTM C-496 (2011) were followed in compression and tensile tests that were performed in a universal testing machine with a loading rate of $1 \mathrm{~mm} / \mathrm{s}$. Data loggers were attached to the universal testing machine to record the displacements and loading.

The slump values were obtained for all three mixtures according to the ASTM C-143 (2015). The slump values for the control mix, quartzite and granite concretes were 86,88 and $85 \mathrm{~mm}$, respectively. The slight differences were potentially due to the different shapes and textures of the aggregates. As was shown in Fig. 1, the limestone had a more rounded shape than quartzite and granite. Although quartzite was angular, it exhibited the smoothest surface texture among all three aggregates.

A compressive strength of $20.48 \mathrm{MPa}$ was obtained [according to ASTM C-39 (2014)] for the control (limestone) concrete that was not subjected to high temperatures. This was very close to the target compressive strength of $21 \mathrm{MPa}$. 
Table 2 Chemical composition of coarse aggregates.

\begin{tabular}{c|c|c|c}
\hline Element & Limestone & Quartzite & Granite \\
\hline $\mathrm{SiO}_{2}$ & 2.69 & 91.14 & 63.05 \\
\hline $\mathrm{Fe}_{2} \mathrm{O}_{3}$ & 0.57 & 2.23 & 5.85 \\
\hline $\mathrm{Al}_{2} \mathrm{O}_{3}$ & 0.16 & 3.38 & 11.26 \\
\hline $\mathrm{CaO}$ & 53.36 & Traces & 13.19 \\
\hline $\mathrm{MgO}$ & 0.21 & Traces & 4.17 \\
\hline $\mathrm{Na}_{2} \mathrm{O}$ & 0.32 & 2.71 & 0.69 \\
\hline $\mathrm{K}_{2} \mathrm{O}$ & 0.41 & 0.3 & 1.08 \\
\hline Loss on ignition & 42.2 & 0.1 & 0.6 \\
\hline
\end{tabular}

Table 3 Amounts of materials for $1 \mathrm{~m}^{3}$ of concrete.

\begin{tabular}{c|c}
\hline Material & Quantity $\left(\mathrm{kg} / \mathrm{m}^{3}\right)$ \\
\hline \hline Cement & 354 \\
\hline Fine aggregate & 699 \\
\hline Coarse aggregate & 1050 \\
\hline Water & 195 \\
\hline
\end{tabular}
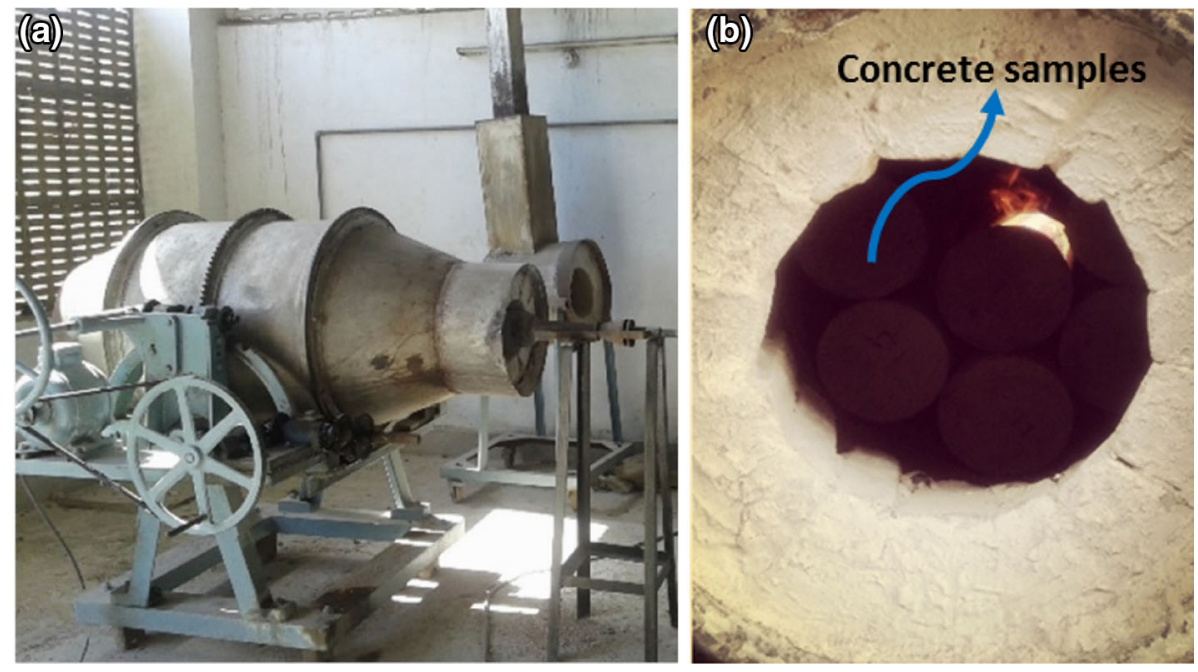

Fig. 3 Temperature exposure of concrete cylinders: a rotary kiln, b specimen being subjected to high temperature.

Quartzite and granite concretes yielded compressive strengths of 28.92 and $35.42 \mathrm{MPa}$, which were 41 and $72 \%$ higher, respectively, than the control mix.

\subsection{Heating Procedure}

After casting, concrete cylinders were cured at room temperature in a water tank. After curing for 28 days, the cylinders were burnt in rotary kiln, as shown in Fig. 3, at $95 \pm 2{ }^{\circ} \mathrm{C}$ $\left(\sim 200{ }^{\circ} \mathrm{F}\right), 205 \pm 2{ }^{\circ} \mathrm{C}\left(\sim 400{ }^{\circ} \mathrm{F}\right), 315 \pm 2{ }^{\circ} \mathrm{C}\left(\sim 600^{\circ} \mathrm{F}\right)$, $425 \pm 2{ }^{\circ} \mathrm{C} \quad\left(\sim 800^{\circ} \mathrm{F}\right), \quad 535 \pm 3{ }^{\circ} \mathrm{C} \quad\left(\sim 1000{ }^{\circ} \mathrm{F}\right)$ and $650 \pm 3{ }^{\circ} \mathrm{C}\left(\sim 1200^{\circ} \mathrm{F}\right)$ for a duration of $2 \mathrm{~h}$. Six cylinders (pertaining to one mixture and one test temperature) were placed in the kiln at a given time. Fire was burnt at the fire exit point of the kiln and the desired inside temperatures were reached at the same heating rate. The temperature was constantly monitored using an infrared thermometer to ensure that it remains constant for the period of exposure, i.e., 2 h. Fire was put off after two hours and the cylinders were left in the kiln for cooling. The cylinders were removed from the kiln after cooling to room temperature. All mechanical tests were performed afterwards under room temperature $\left(25 \pm 1{ }^{\circ} \mathrm{C}\right)$.

\subsection{Resistance to Degradation and X-ray Diffraction Tests}

In addition to the mechanical properties of concrete, the effect of elevated temperatures on strength of the three coarse aggregates was investigated. These three aggregates 
were burnt in the same conditions as concrete (at the six high temperatures for $2 \mathrm{~h}$ ). The resistance to degradation of original and heat treated aggregates was determined using a Los Angeles abrasion machine according to ASTM C131/ C131M (2014).

Phase compositions of these three aggregates were investigated on the fine powders using X-ray diffraction method. The powder samples of original aggregates, and those of the heat treated aggregates at 315 and $650{ }^{\circ} \mathrm{C}$, were collected after abrasion. X-ray diffraction analysis was performed on an X-ray diffractometer with a $\theta-2 \theta$ configuration using $\mathrm{CuK} \alpha$ source $(\lambda=1.54 \AA)$. The samples were scanned in step mode with a step size of $0.05^{\circ}(2 \theta)$ at $-40 \mathrm{kV}$ and $30 \mathrm{~mA}$.

\section{Results and Discussion}

\subsection{Effect of High Temperature on Resistance to Degradation of Aggregates}

The resistance to degradation of the three aggregates under elevated temperatures is shown in Fig. 4. Prior to heat treatment, granite and limestone exhibited the lowest and highest losses by abrasion and impact, indicating that these two aggregates have the highest and lowest strength, respectively. This might be attributed to the difference in mineral compositions and aggregate shapes. Limestone and quartzite mainly consisted of calcite and quartz, respectively. The primary constituents of granite were quartz and feldspars. With a hardness of 7.0, quartz is harder and stronger than calcite under room temperature. However, as shown in Fig. 4, quartzite aggregate, which contained the highest quartz fraction with an evident angular shape, yielded a strength value in between. This is believed to be the main reason for the difference in compressive strength of concretes. Under elevated temperature, cracks gradually generated and the cracking density, intracrystalline crack length, and crack width of aggregates increased. As a result, the elastic modulus and strength were reduced considerably.

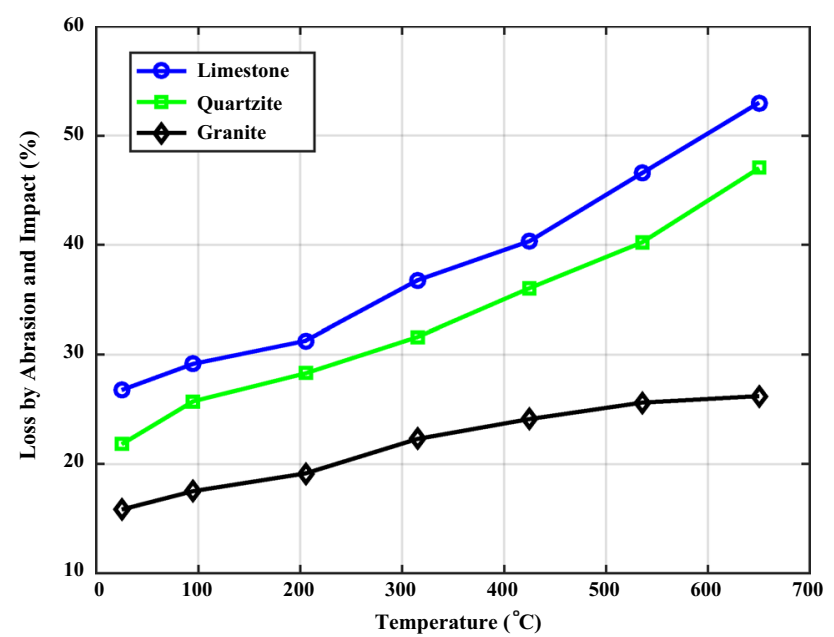

Fig. 4 Resistance to degradation of aggregates subjected to high temperature.
Limestone and granite yielded highest and lowest loss by abrasion, respectively, under elevated temperatures. The main difference occurs when temperature exceeded $300{ }^{\circ} \mathrm{C}$ : the loss by abrasion of limestone increased by $44.2 \%$, however a slight increase $(17.8 \%)$ was observed in granite. As reported by Zhang et al. (2015), $300{ }^{\circ} \mathrm{C}$ is the damage threshold temperature for limestone, and in the range from 300 to $600{ }^{\circ} \mathrm{C}$, significant damage occurs due to formation of internal defects, such as micropores, cracks and transgranular fractures. This is in agreement with the observations of Chen et al. (2009) that microcracks appear when limestone is heated to $300{ }^{\circ} \mathrm{C}$ and mineral particles crack and clear fractures appear when heated to $500{ }^{\circ} \mathrm{C}$. Accordingly, based on the results here and data in literature, it may be anticipated that limestone concrete will have a lower strength than quartzite and granite concretes after heat treatment. It will be shown later in this paper that the strengths of concretes subjected to elevated temperatures parallel these observations.

\subsection{Temperature Dependence of Mechanical Properties of Concrete}

Subjecting the samples to high temperatures decreased the concrete compressive strength at $650{ }^{\circ} \mathrm{C}$ to $6.77 \mathrm{MPa}, 10.00$ and $19.08 \mathrm{MPa}$, respectively, for limestone, quartzite and granite concrete. The compressive strength values at different temperatures are shown in Fig. 5a. The percent loss values with respect to the original strength of concretes is shown in Fig. 5b. In absolute terms, granite concrete had higher compressive strength in room temperature and retained higher strength at increasing temperatures compared to quartzite and limestone concrete. As shown in Fig. 5b, granite concrete exhibited a considerably less relative (to original) strength reduction rate than quartzite and limestone concrete, which showed similar percent loss values with respect to their original strength as temperature increased. This might be partially attributed to the low temperature dependence of the strength of granite as presented in Fig. 4. As seen in Fig. 5a, a first order polynomial fitted well to the compressive strength-temperature curve in linear scale. It was obtained that the compressive strength of limestone, quartzite and granite aggregate decrease by approximately 2.16, 2.94 and $2.65 \mathrm{MPa}$, respectively, for every $100{ }^{\circ} \mathrm{C}$ increase in temperature, which were found to be comparable.

At $25{ }^{\circ} \mathrm{C}$ limestone concrete provided a tensile strength of $2.47 \mathrm{MPa}$ while the same for quartzite and granite concretes was 3.14 and $3.99 \mathrm{MPa}$ (27 and $62 \%$ higher), respectively. At $650{ }^{\circ} \mathrm{C}$ the tensile strength of limestone, quartzite and granite concretes was $0.60,0.95$ and $1.77 \mathrm{MPa}$, respectively. The tensile strength at different temperatures is shown in Fig. 6a while the percent loss values are shown in Fig. 6 b. The line fits indicate that the tensile strength of limestone, quartzite and granite concrete decrease by $0.29,0.34$ and $0.36 \mathrm{MPa}$, respectively, for every $100{ }^{\circ} \mathrm{C}$ increase in temperature. These results indicate that limestone concrete performs slightly better in terms of retaining its absolute strength with temperature compared to quartzite and granite concrete which showed very similar results. However, from 
(a)

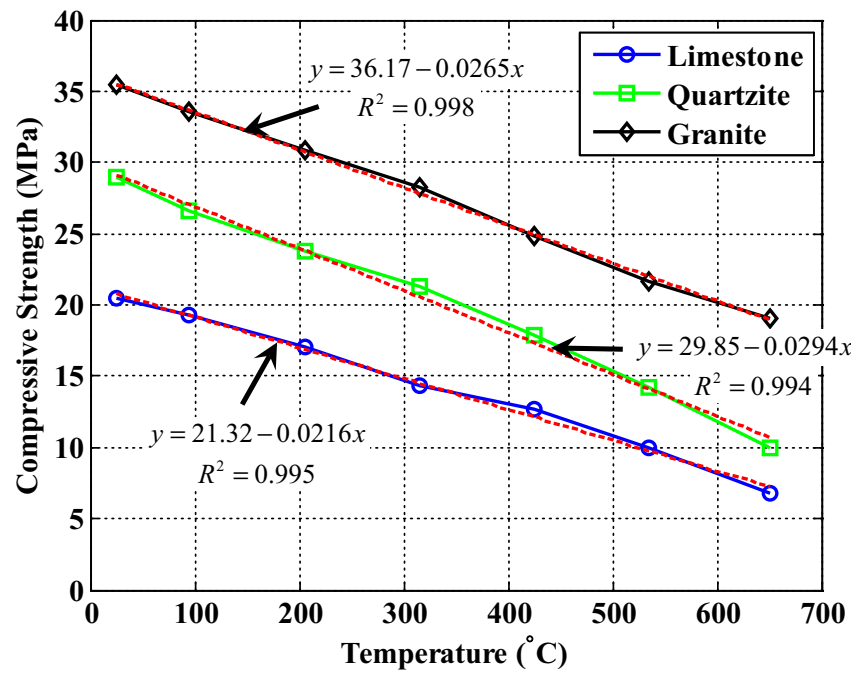

(b)

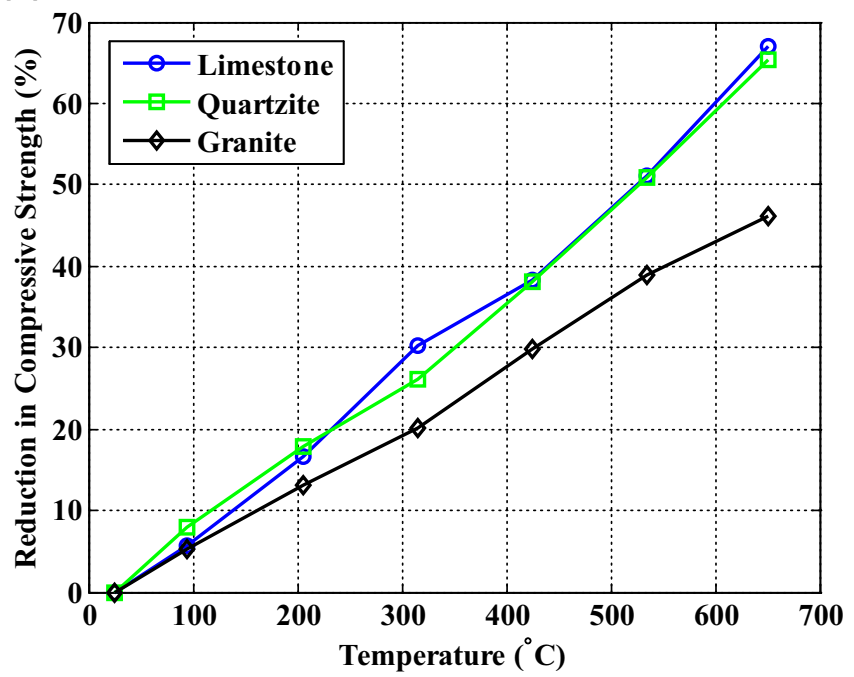

Fig. 5 a Compressive strength of concretes at different temperatures, b change in compressive strength with temperature.

(a)

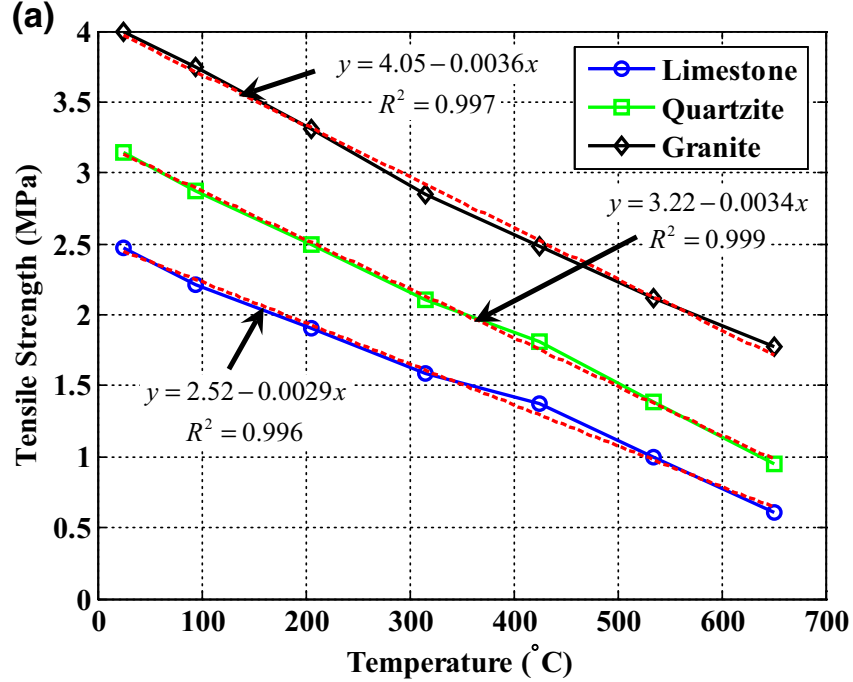

(b)

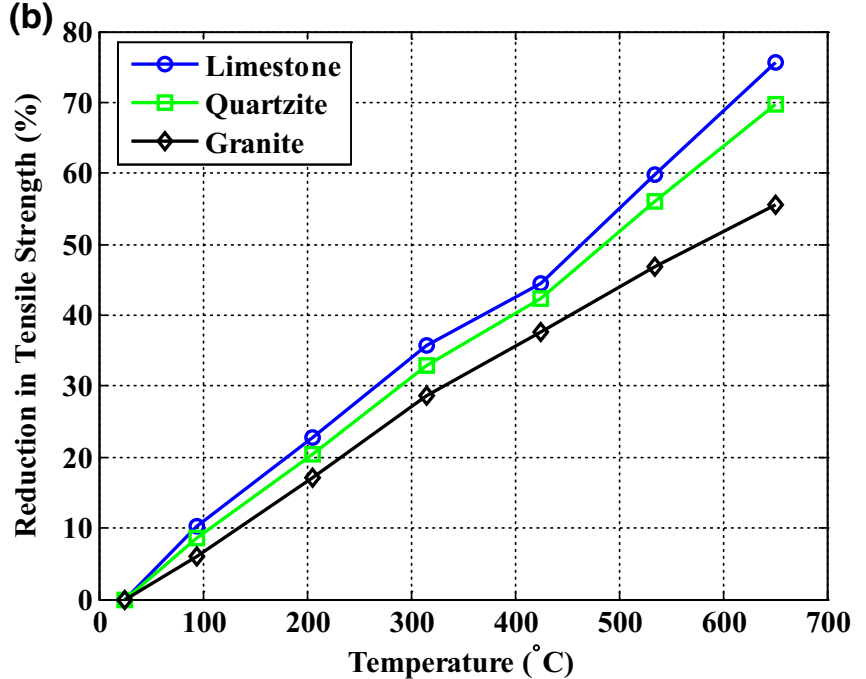

Fig. 6 a Tensile strength of concretes at different temperatures, b change in tensile strength with temperature.

Fig. 6b, a similar trend as compressive strength was observed in the rate of relative strength loss under increasing temperature. This again indicated that, given its higher original strength and low temperature sensitivity of granite, the granite concrete yields a lower degradation rate of relative strength than limestone and quartzite concrete as the temperature increases.

The stress-strain responses were recorded for all the samples during compressive testing. The results are shown in Figs. 7, 8 and 9 for limestone, quartzite and granite concrete, respectively. The ultimate compressive strains (taken as the value corresponding to the peak stress) were observed to be different for different concretes and dependent on the temperature. For the same concrete, increasing the temperature resulted in an increase in the ultimate strain values (hence the ductility of the material). The ultimate strain values for all of the mixes at different temperatures are shown in Fig. 10a while the percent increase values are shown in Fig. 10b. As seen in Fig. 10a, quartzite concrete had the highest ultimate compressive strain passed $200{ }^{\circ} \mathrm{C}$ followed by limestone and granite concrete. For temperatures lower than $200{ }^{\circ} \mathrm{C}$, limestone concrete showed the

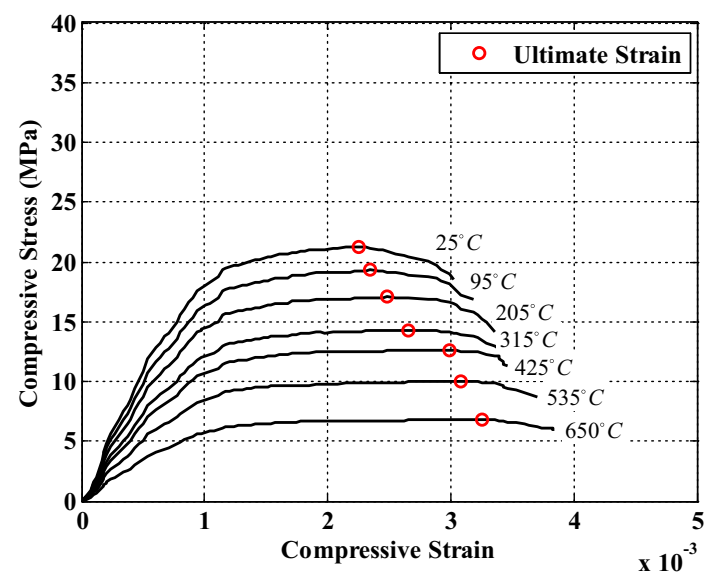

Fig. 7 Stress-strain curves for limestone concrete at different temperatures. 


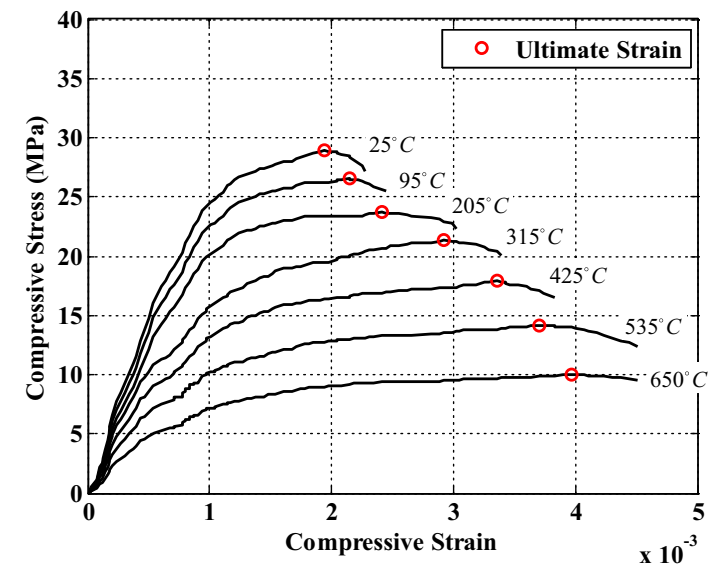

Fig. 8 Stress-strain curves for quartzite concrete at different temperatures.

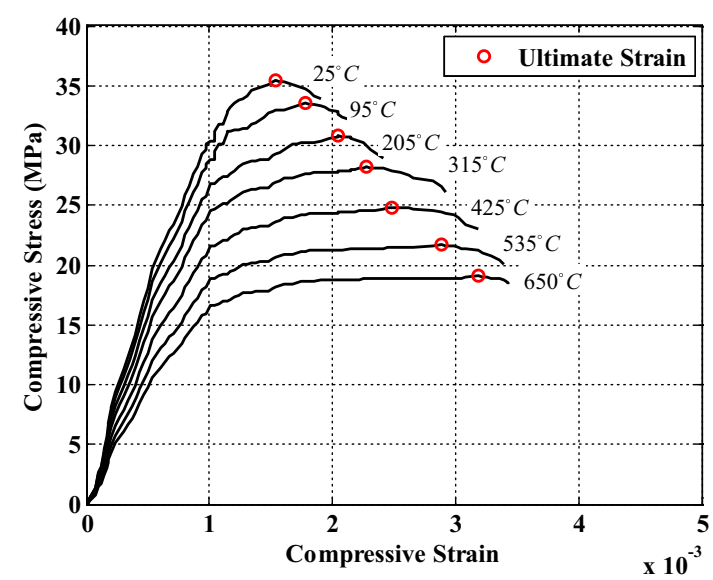

Fig. 9 Stress-strain curves for granite concrete at different temperatures.

highest ultimate compressive strain followed by quartzite and granite concrete. Again, a linear relationship was found to represent well the change of ultimate compressive strain with temperature. Limestone concrete showed the least change in its ultimate compressive strain with increasing temperature while quartzite and granite concretes showed a similar behavior.

The compressive chord modulus of elasticity of concrete was calculated according to ASTM C-469 (2014). At $25{ }^{\circ} \mathrm{C}$, the limestone concrete provided an elastic modulus of 23.0 GPa while the same for quartzite and granite concretes was 31.2 and $38.2 \mathrm{GPa}$ (36 and $66 \%$ higher), respectively. The elastic moduli at different temperatures are shown in Fig. 11a while the percent change is provided in Fig. 11b. The granite concrete had the highest elastic modulus at all temperatures followed by quartzite and limestone concrete. A linear fit to the data indicated that the modulus of elasticity of limestone, quartzite and granite concrete decreased 2.41, 3.26 , and $2.86 \mathrm{GPa}$, respectively, for every $100{ }^{\circ} \mathrm{C}$ increase in temperature. The information in Fig. $11 \mathrm{~b}$ indicates that, the same observations as for compressive and tensile strength could be made, that is the rate of decrease of the relative modulus of granite concrete is lower than that of limestone and quartzite concrete.

\subsection{Thermal Expansion}

Given that concrete is a heterogeneous composite mixture, the deterioration of concrete under elevated temperature consists of complex interactions between physical and mechanical processes, such as dehydration and decomposition of cement paste, degradation of aggregates, and damage to the matrix due to the differences in the thermal expansion behavior of different components. In this study, the dehydration of cement paste can be assumed to be the same for all concretes, as a result, the differences in their temperature dependencies were due to the degradation of aggregates and cracking caused by thermal stresses generated by the imparity in thermal expansion behavior of cement paste and aggregates.

Thermal expansion represents the volume change of a material due to temperature change and it is important (a)

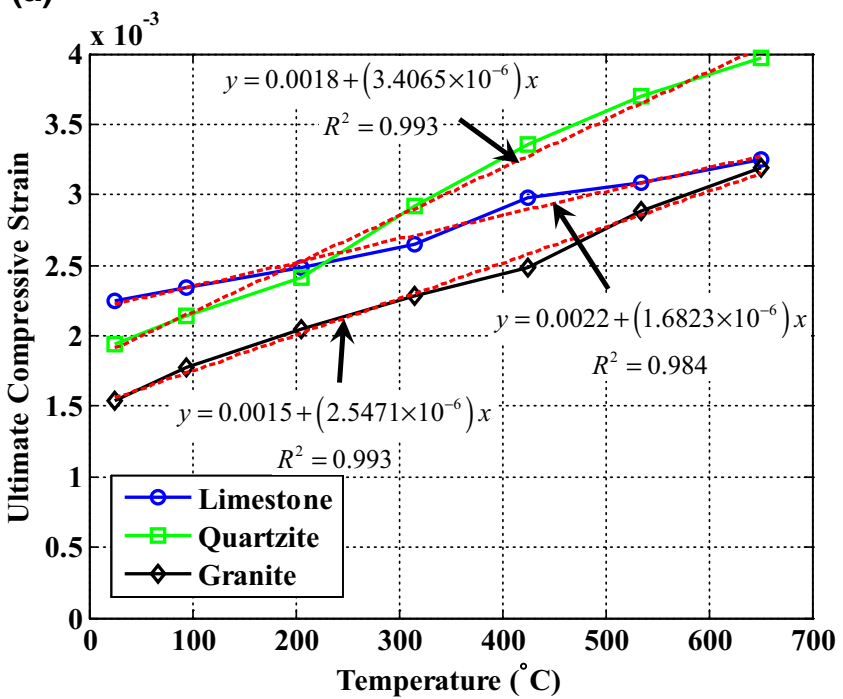

(b)

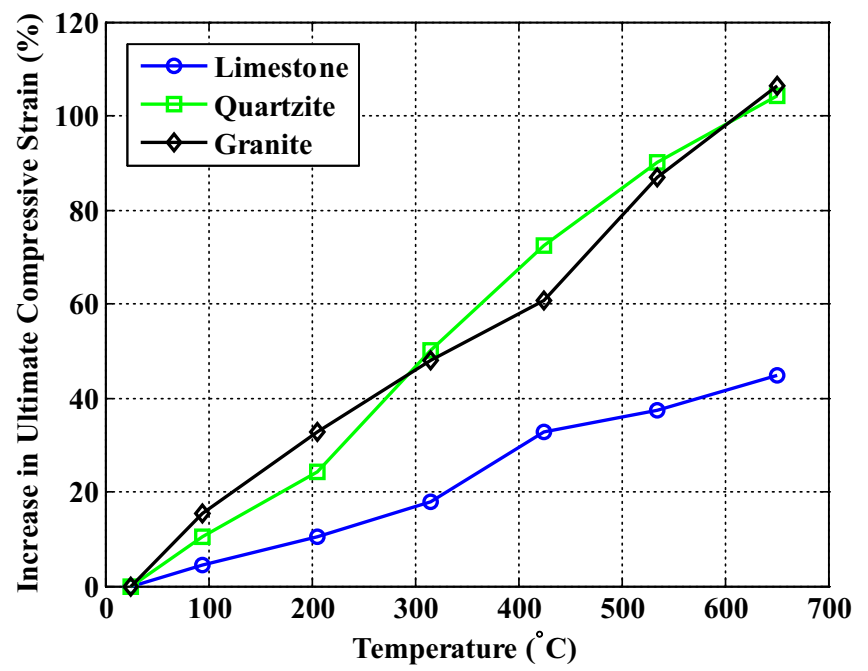

Fig. 10 a Ultimate compressive strain of concretes at different temperatures, $\mathbf{b}$ change in ultimate compressive strain with temperature. 
(a)

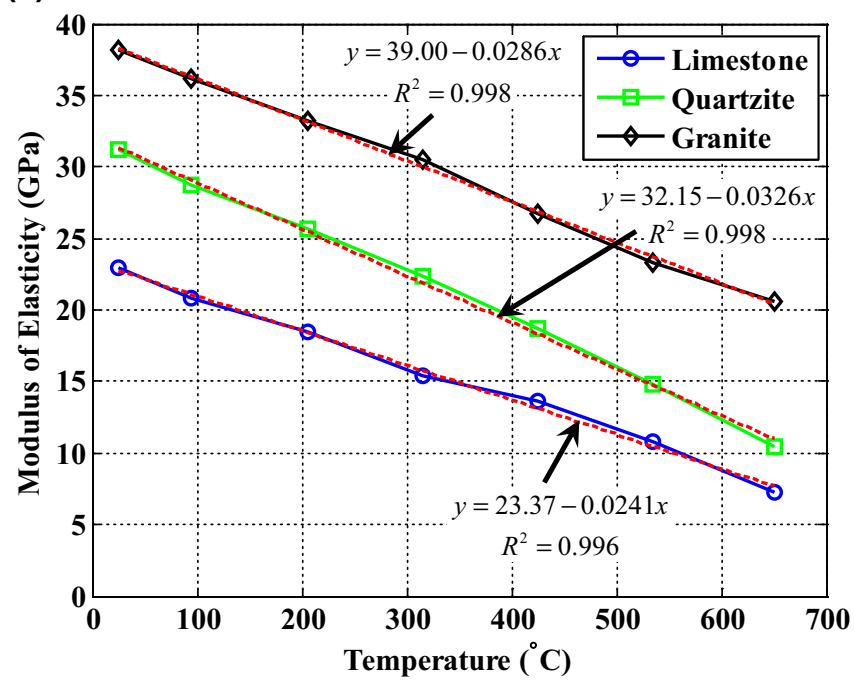

(b)

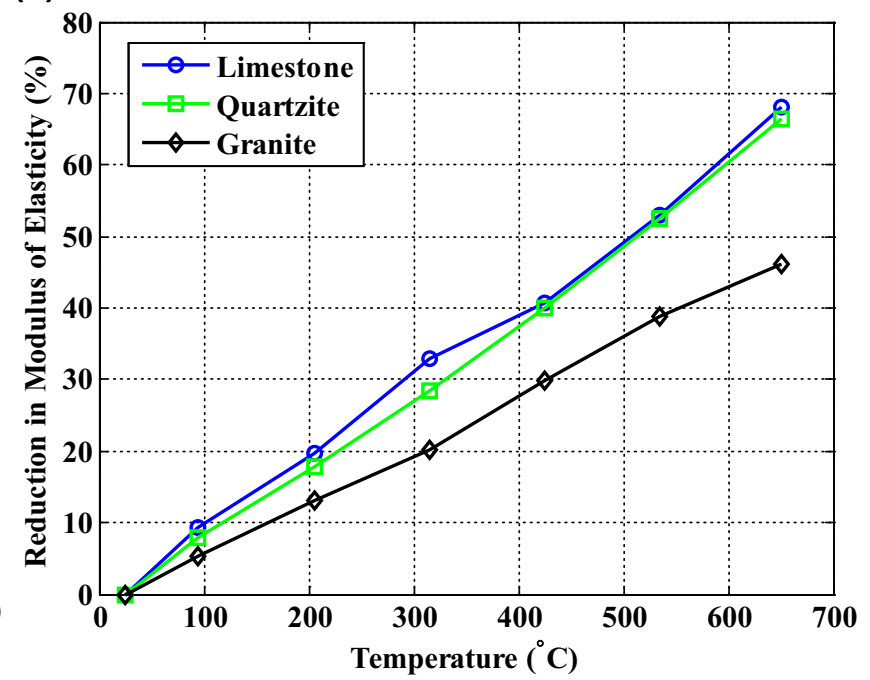

Fig. 11 a Modulus of elasticity of concretes at different temperatures, $\mathbf{b}$ change in modulus of elasticity with temperature.

because it can result in thermal stresses and structural movement that can lead to concrete cracking and spalling (Naus 2010). Thermal expansion and contraction behavior of concrete varies primarily with aggregate type, cementitious material content, w/c ratio, temperature range, concrete age, and ambient relative humidity, and of these factors, aggregate type was found to have the greatest influence on the expansion and contraction of concrete (Yao and Zheng 2007). Moisture content, w/c ratio, and type of cement were found to only affect the thermal expansion at relatively low temperatures, i.e., $T<200{ }^{\circ} \mathrm{C}$ (Naus 2010). For a constant amount of water, the coefficient of thermal expansion of concrete reduces with decreasing cement content (Yao and Zheng 2007). In addition, in a temperature range from 100 to $1000{ }^{\circ} \mathrm{C}$, the coefficient of thermal expansion decreases with increasing porosity of aggregates, therefore, a lower expansion is observed in concretes with lightweight (porous) aggregate in comparison to those that contain normal weight aggregates (Uygunoglu and Topçu 2012). It should be noted that, for temperatures below $150{ }^{\circ} \mathrm{C}$, as the temperature is increased, a volume expansion in cement paste takes place. When the temperature exceeds $150{ }^{\circ} \mathrm{C}$, Portland cement paste starts contracting with increasing temperature (Cruz and Gillen 1980; Naus 2010), which is attributed to the dehydration of cement hydration products, such as calcium hydroxide and $\mathrm{C}-\mathrm{S}-\mathrm{H}$ gels.

Among the three aggregates considered here, quartzite exhibits the highest linear thermal expansion coefficient, therefore, the quartzite concrete has potentially yielded a higher volume expansion than limestone and granite concretes. This might be attributed to the high silica (quartz) fraction in quartzite. Naus (2010) presented that the largest expansion always occurs for aggregates having the highest percentage of silica by weight. In the presence of anorthite, which has an even lower thermal expansion than calcite, granite shows a lower coefficient of thermal expansion than quartzite. Due to the low temperature sensitivity of volume change of calcite, limestone and limestone concrete have potentially shown the lowest thermal expansion among the three aggregates and concretes, respectively. However, it should be noted that, different from the pure volume expansion of quartzite and granite, cracking of mineral particles and the formation of fractures in limestone are the most important factors for heat expansion of limestone (Chen et al. 2009). Moreover, the anisotropic expansion behavior can be observed in these aggregates under elevated temperature (Chen et al. 2009; Plevova et al. 2016). Due to the thermal shrinkage of cement paste and the considerable thermal expansion of aggregates, a net expansion of concrete is exhibited and inner thermal stresses are generated. Once these stresses become greater than the Portland cement tensile capacity or aggregate strength, micro-cracking occurs. Under high temperature, the strength of cement pastes is reduced due to dehydration and decomposition. This in turn reduces the stress threshold for crack generation and propagation. These cracks generate new surfaces that are directly exposed to high temperatures, hence the temperature gradient may significantly change and the cracking deterioration could accelerate (Pancar and Akpinar 2016).

\subsection{Phase Transformation}

In addition to dehydration of cement paste, thermal expansion and cracking, crystal transformation and mineral decomposition of aggregates are considered as important reasons for deterioration of concrete under elevated temperature. As shown in Fig. 12, the limestone aggregate used in this study composed primarily of calcium carbonate $\left(\mathrm{CaCO}_{3}\right)$ in the form of the mineral calcite and a small amount of quartz. As temperature increased, the intensity of quartz increased first and then decreased. This is attributed to the partial decomposition of calcite and phase transition of quartz. At atmospheric pressure, decomposition of calcite does not start until temperature exceeds $850{ }^{\circ} \mathrm{C}$. In fact, the conversion starts at a temperature of about $600{ }^{\circ} \mathrm{C}$, and 

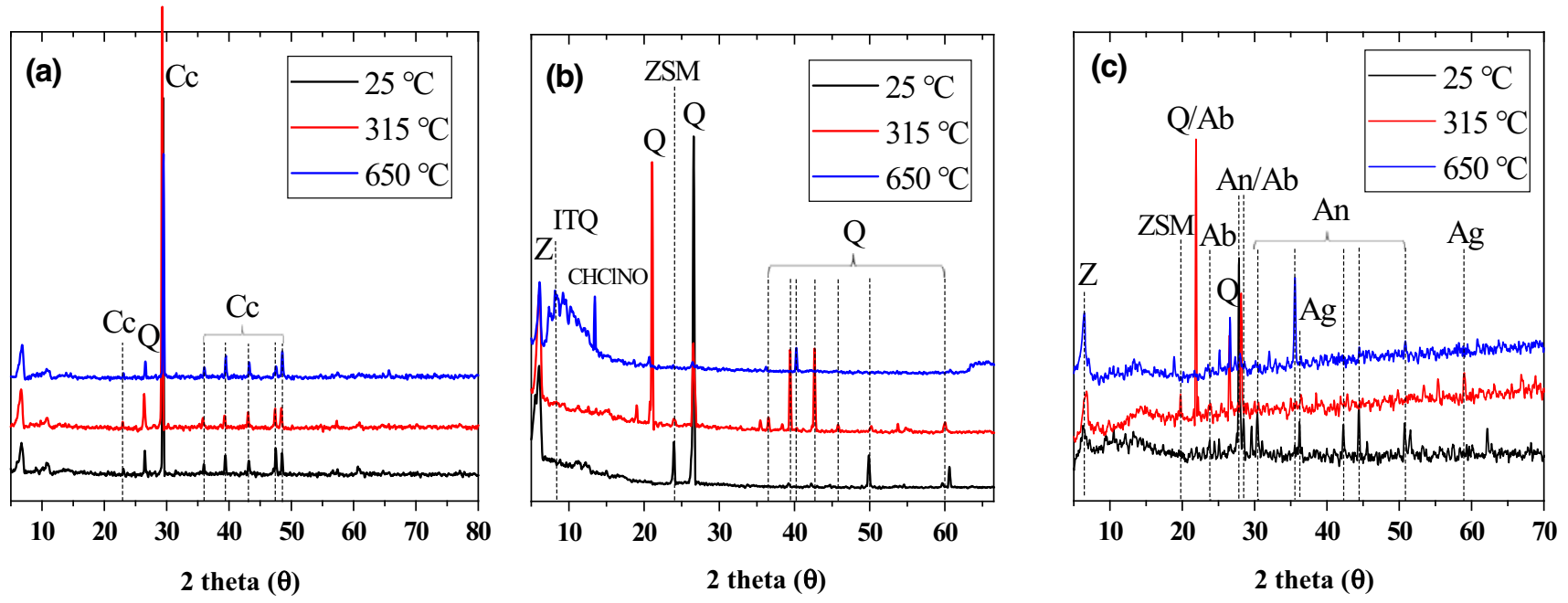

Fig. $12 \mathrm{XRD}$ pattern of mineral components in a limestone, b quartzite and $\mathbf{c}$ granite aggregates (Notes: Cc calcite, $Q$ quartz, $Z$ Zeolite, ITQ calcined ITQ-4 $\left(\mathrm{Si}_{24} \mathrm{O}_{48}\right), Z S M$ ZSM-23 $\left(\mathrm{Si}_{24} \mathrm{O}_{48}\right), A b$ albite, $A n$ anorthite, $A g$ augite).

finishes at $850{ }^{\circ} \mathrm{C}$ with a loss of $44 \mathrm{wt} \%$ corresponding to the stoichiometric $\mathrm{CO}_{2}$ amount in $\mathrm{CaCO}_{3}$ (RodriguezNavarro et al. 2009). It should be noted that the decomposition of limestone occurs in a similar temperature range as thermal degradation of $\mathrm{C}-\mathrm{S}-\mathrm{H}$. This partial thermal decomposition of calcite, combined with the inner defects (e.g., cracks and fractures) formed under elevated temperatures, resulted in significant changes in mechanical properties of the aggregates (as shown in Fig. 4). Therefore, although limestone has the lowest thermal expansion, the limestone concrete yielded the lowest strength at all test temperatures and the highest relative rate of strength decrease.

As shown in Fig. 12, the quartzite aggregates mainly consisted of quartz. Peaks of zeolite and ZSM-23 $\left(\mathrm{Si}_{24} \mathrm{O}_{48}\right)$ were also detected. In the range of 25 to $315{ }^{\circ} \mathrm{C}$, the effect of temperature on the phase composition of quartzite was mild: only the change of degree for quartz peaks and the disappearance of ZSM-23 were detected. The degree of crystallinity was increased by $2.4 \%$. When temperature was raised to $650{ }^{\circ} \mathrm{C}$, the quartz phase transformed substantially. The intensity of zeolite phase decreased and two new peaks for calcined ITQ-4 and $\mathrm{C}_{22} \mathrm{H}_{20} \mathrm{C}_{12} \mathrm{~N}_{4} \mathrm{O}_{8}$ were observed. Under normal pressure, trigonal quartz (also named $\alpha$-quartz or low quartz) transforms into hexagonal $\beta$-quartz (high quartz) at $573{ }^{\circ} \mathrm{C}$, and upon further heating the $\mathrm{SiO}_{2}$ transforms into hexagonal $\beta$-tridymite at $870{ }^{\circ} \mathrm{C}$ and later to cubic $\beta$-cristobalite at $1470{ }^{\circ} \mathrm{C}$ (Wenk and Bulakh 2004; Akhavan 2005). In the temperature range of this study, only the first phase transition occurred. The density of $\alpha$-quartz and hexagonal $\beta$-quartz is 2.65 and $2.53 \mathrm{~g} / \mathrm{cm}^{3}$, respectively (Akhavan 2005). As a result, a slight discontinuous thermal expansion caused by phase change was observed. As this process is reversible only when the temperature changes very slowly, it is believed that there was residual hexagonal $\beta$-quartz after cooling. In addition, it should be noted that a wide dispersion peak was found between $6.5^{\circ}$ and $13^{\circ}(2 \theta)$ for the quartzite sample after $650{ }^{\circ} \mathrm{C}$ (Fig. 12). This indicates that amorphous phases were formed in quartzite aggregate under high temperature. As a result, the degree of crystallinity of quartzite aggregate decreased by about $78 \%$.

The main constituents of granite aggregates in this study, as indicated in Fig. 12 were quartz and two plagioclase feldspars: albite $\left(\mathrm{NaAlSi}_{3} \mathrm{O}_{8}\right)$ and anorthite $\left(\mathrm{CaAl}_{2} \mathrm{Si}_{2} \mathrm{O}_{8}\right)$. Augite and zeolite were also detected in XRD pattern as minor phases. With increasing temperature, a same phase transition of quartz as that in quartzite aggregate was observed. Given the short heat treatment time, no significant disordering or phase transformation was detected in the feldspars within the test temperature range of this study. This was found to be in good agreement with the previous observations indicating that low and high albites are stable below 650 and $725^{\circ} \mathrm{C}$, respectively, under low pressure (disordering rates of low albite on dry heating at atmospheric pressure is of the order of 150-200 days at $950{ }^{\circ} \mathrm{C}$ ) (Brown 1989). The anorthite phase is also stable under low pressure, and even at high temperature, the breakdown reaction of feldspar anorthite is difficult due to the slow reaction rate at temperatures below $1200{ }^{\circ} \mathrm{C}$ (Goldsmith 1980). Given the low fraction of quartz phase, granite was more stable than quartzite under elevated temperatures and this agrees well with the temperature dependence of resistance to abrasion of aggregates as shown in Fig. 4.

According to the test results and analysis above, it can be concluded that deterioration of these concretes were caused by different mechanism. Among the three aggregates, the most serious degradation was observed in limestone, mainly attributed to the formation of inner fractures and cracks of mineral particles, as well as the partial decomposition of calcite under higher temperature. As a result, the highest relative strength reduction was yielded by the limestone concrete at all test temperatures, although this aggregate had the lowest thermal expansion among the three groups. In contrary to limestone, the significant thermal expansion behavior of quartz phase and its phase transition when 
temperature exceeded $573{ }^{\circ} \mathrm{C}$ were identified to be the main reasons for the reduction of strength in quartzite concrete. Given its low quartz fraction (indicating low thermal expansion and low impact from phase transformation) and the high stability of the two plagioclase feldspars (albite and anorthite), granite concrete showed the lowest temperature dependence of mechanical properties among the three groups.

\section{Conclusions}

In this paper, the effect of different coarse aggregates; namely, limestone, quartzite and granite, on the mechanical properties of concretes subjected to elevated temperatures from 95 to $650{ }^{\circ} \mathrm{C}$ were studied. The following conclusions were drawn from the obtained results:

- The type of aggregate used in this study had no considerable effect on the workability of the concrete mix as very similar slump values were achieved for limestone, quartzite and granite. Since the aggregates were in surface dry saturated condition, the slight differences in the slump values may be attributed to the shape and texture of the aggregates.

- At 28 days and no elevated temperature exposure, granite and quartzite concrete, respectively, yielded 41 and $72 \%$ higher compressive strength, 27 and $62 \%$ higher tensile strength, and 36 and $66 \%$ higher elastic modulus in comparison to limestone concrete. This indicates that properties of aggregate substantially impact the mechanical properties of concrete.

- For every concrete mix, the compressive and tensile strength, and elastic modulus were observed to be inversely proportional to temperature; while the ultimate strain in compression was directly proportional. Although ultimate strength of these concretes were reduced by different amounts, their deformability in compression was improved after heat treatment.

- Granite concrete had the highest compressive and tensile strength and elastic modulus at all test temperatures in comparison to quartzite and limestone concretes. The compressive and tensile strength, and elastic modulus, respectively, of granite concrete was 182,195 and $182 \%$ higher than that of limestone concrete, and 191, 186 and $97 \%$ higher than that of quartzite concrete at $650{ }^{\circ} \mathrm{C}$.

- A linear relationship represented well the temperature dependency of mechanical properties. The compressive and tensile strength, and the elastic modulus of limestone, quartzite and granite concrete, respectively, decreased by $2.16,2.94$ and $2.65 \mathrm{MPa}$ (compression), $0.29,0.34$ and $0.36 \mathrm{MPa}$ (tension), and 2.41, 3.26 and $2.86 \mathrm{GPa}$ (modulus) for every $100{ }^{\circ} \mathrm{C}$ increase in temperature.

- Compared to limestone and quartzite concrete, a lower relative (to original value) rate of decrease of compressive strength, tensile strength and elastic modulus under elevated temperatures were observed for granite concrete under increasing temperatures. However, the lowest rate of increase of ultimate compressive strain was yielded by the limestone concrete.

- Degradation of coarse aggregates was considered as one of the primary reasons for the decreased mechanical properties of concretes under elevated temperature. The resistances to abrasion and impact of all these three aggregates decreased with increasing temperature. Limestone and granite yielded the highest and the lowest loss by abrasion, respectively. The main difference occurred when temperature exceeded $300{ }^{\circ} \mathrm{C}$, which is the damage threshold temperature of limestone to form inner defects.

- Due to high quartz fraction, quartzite exhibits the highest linear thermal expansion coefficient among the three aggregates. When the temperature exceeded $150{ }^{\circ} \mathrm{C}$, Portland cement paste contracted with increasing temperature. The thermal shrinkage of the cement paste and expansion of aggregates have potentially resulted in thermal stresses in the cement pastes causing micro-cracking. Due to dehydration and decomposition of $\mathrm{C}-\mathrm{S}-\mathrm{H}$ phases, which substantially decrease the tensile strength of cement pastes, the damage was significantly accelerated under high temperature.

- Although no significant phase transformation occurred in the limestone, a partial thermal decomposition was detected under high temperature. Different from quartzite and granite, the thermal expansion of limestone was mainly caused by cracking of mineral particles and the formation of fractures. Therefore, although it showed the lowest temperature sensitivity in volume change, limestone aggregate and limestone concrete yielded the highest relative strength and modulus reduction among the three concretes.

- According to the XRD patterns and the phase diagram, a phase transition of quartz occurred in quartzite and granite aggregates when temperature exceeded $573{ }^{\circ} \mathrm{C}$. Given the low fraction of quartz phase and the presences of stable albite and anorthite phases in granite, less phase conversion and thermal expansion occurred in granite in comparison to quartzite. Therefore, granite exhibited better resistance to degradation than limestone and quartzite at all test temperatures. This is considered as the main reason for the highest resistance of mechanical properties of granite concrete among the three groups when subjected to elevated temperatures.

\section{Open Access}

This article is distributed under the terms of the Creative Commons Attribution 4.0 International License (http://creativecommons.org/licenses/by/4.0/), which permits unrestricted use, distribution, and reproduction in any medium, provided you give appropriate credit to the original 
author(s) and the source, provide a link to the Creative Commons license, and indicate if changes were made.

\section{References}

Abrams, M. S. (1971). Compressive strength of concrete at temperatures to 1600F. ACI Special Publication, 25, 33-58.

ACI. (2014). Building code requirements for structural concrete (ACI 318-14) and commentary (ACI 318-14R). American Concrete Institute (ACI): Farmington Hills, MI.

Akhavan, A. C. (2005). The quartz page. Retrieved 07/24, 2016. http://www.quartzpage.de/gen_mod.html.

Ali, F., Nadjai, A., Silcock, G., \& Abu-Tair, A. (2004). Outcomes of a major research on fire resistance of concrete columns. Fire Safety Journal, 39(6), 433-445.

Arioz, O. (2007). Effects of elevated temperatures on properties of concrete. Fire Safety Journal, 42(8), 516-522.

ASTM. (2009). Standard test method for bulk density ("Unit Weight") and voids in aggregate. West Conshohocken, PA: American Society for Testing of Materials (ASTM). C29/ C29M-09.

ASTM. (2011). Standard test method for splitting tensile strength of cylindrical concrete specimens. West Conshohocken, PA: American Society of Testing Materials (ASTM). ASTM C496-11.

ASTM. (2013). Standard specification for concrete aggregates. West Conshohocken, PA: American Society for Testing of Materials (ASTM). C33/C33M-13.

ASTM. (2013). Standard test method for surface moisture in fine aggregate. West Conshohocken, PA: American Society of Testing Materials (ASTM). ASTM C70-13.

ASTM. (2013). Standard test method for total evaporable moisture content of aggregate by dryin. West Conshohocken, PA: American Society of Testing Materials (ASTM). ASTM C566-13.

ASTM. (2014). Standard test method for compressive strength of cylindrical concrete specimens. West Conshohocken, PA: American Society of Testing Materials (ASTM). ASTM C39/C39M-14.

ASTM. (2014). Standard test method for resistance to degradation of small-size coarse aggregate by abrasion and impact in the Los Angeles machine. West Conshohocken, PA: American Society for Testing and Materials (ASTM). C131/C131M-14.

ASTM. (2014). Standard test method for sieve analysis of fine and coarse aggregates. West Conshohocken, PA: American Society for Testing of Materials (ASTM). ASTM C136/ C136M-14.

ASTM. (2014). Standard test method for static modulus of elasticity and Poisson's ratio of concrete in compression. West Conshohocken, PA: American Society of Testing Materials (ASTM). ASTM C469/C469M-14.

ASTM. (2015). Standard test method for density, relative density (specific gravity), and absorption of coarse aggregate. West Conshohocken, PA: American Society of Testing Materials (ASTM). ASTM C127-15.
ASTM. (2015). Standard test method for density, relative density (specific gravity), and absorption of fine aggregate. West Conshohocken, PA: American Society of Testing Materials (ASTM). ASTM C128-15.

ASTM. (2015). Standard test method for slump of hydraulic-cement concrete. West Conshohocken, PA: American Society for Testing of Materials (ASTM). ASTM C143/C143M-15.

Behnood, A., \& Ghandehari, M. (2009). Comparison of compressive and splitting tensile strength of high-strength concrete with and without polypropylene fibers heated to high temperatures. Fire Safety Journal, 44(8), 1015-1022.

Behnood, A., \& Ziari, H. (2008). Effects of silica fume addition and water to cement ratio on the properties of high-strength concrete after exposure to high temperatures. Cement \& Concrete Composites, 30(2), 106-112.

Bentz, D. P. (2007). Transient plane source measurements of the thermal properties of hydrating cement pastes. Materials and Structures, 40(10), 1073-1080.

Bentz, D. P., Peltz, M. A., Duran-Herrera, A., Valdez, P., \& Juarez, C. A. (2011). Thermal properties of high-volume fly ash mortars and concretes. Journal of Building Physics, 34(3), 263-275.

Brown, W. L. (1989). Alkali feldspars: Ordering rates, phase transformations and behaviour diagrams for igneous rocks. Mineralogical Magazine, 53(369), 25-42.

Chen, L.-J., He, J., Chao, J.-Q., \& Qin, B.-D. (2009). Swelling and breaking characteristics of limestone under high temperatures. Mining Science and Technology (China), 19(4), 503-507.

Cheng, F., Kodur, V., \& Wang, T. (2004). Stress-strain curves for high strength concrete at elevated temperatures. Journal of Materials in Civil Engineering, 16(1), 84-90.

Cruz, C. R., \& Gillen, M. (1980). Thermal expansion of Portland cement paste, mortar and concrete at high temperatures. Fire and Materials, 4(2), 66-70.

EN. (1992). Design of concrete structures. Part 1-2: General rules-structural fire design. Brussels, Belgium: European Standards (EN).

Ghandehari, M., Behnood, A., \& Khanzadi, M. (2009). Residual mechanical properties of high-strength concretes after exposure to elevated temperatures. Journal of Materials in Civil Engineering, 22(1), 59-64.

Gluekler, E. L. (1979). Local thermal and structural behavior of concrete at elevated temperatures. 5th international conference on structural mechanics in reactor technology Berlin: International Association.

Goldsmith, J. R. (1980). The melting and breakdown reactions of anorthite at high pressures and temperatures. American Mineralogist, 65, 272-284.

Hager, I. (2013). Behaviour of cement concrete at high temperature. Bulletin of the Polish Academy of Sciences: Technical Sciences, 61, 145.

Heikal, M. (2000). Effect of temperature on the physico-mechanical and mineralogical properties of homra pozzolanic cement pastes. Cement and Concrete Research, 30(11), $1835-1839$.

Husem, M. (2006). The effects of high temperature on compressive and flexural strengths of ordinary and high-performance concrete. Fire Safety Journal, 41(2), 155-163. 
Koksal, F., Gencel, O., Brostow, W., \& Lobland, H. E. H. (2012). Effect of high temperature on mechanical and physical properties of lightweight cement based refractory including expanded vermiculite. Materials Research Innovations, 16(1), 7-13.

Li, H., \& Liu, G. (2016). Tensile properties of hybrid fiberreinforced reactive powder concrete after exposure to elevated temperatures. International Journal of Concrete Structures and Materials, 10(1), 29-37.

Naus, D. (2010). In: D. J. Naus (Ed.), A compilation of elevated temperature concrete material property data and information for use in assessments of nuclear power plant reinforced concrete structures. U.S. Nuclear Regulatory Commission, Office of Nuclear Regulatory Research. Report no: NUREG/CR-7031, Washington, DC.

Pancar, E. B., \& Akpınar, M. V. (2016). Temperature reduction of concrete pavement using glass bead materials. International Journal of Concrete Structures and Materials, 10(1), 39-46.

Peng, G.-F., \& Huang, Z.-S. (2008). Change in microstructure of hardened cement paste subjected to elevated temperatures. Construction and Building Materials, 22(4), 593-599.

Plevova, E., Vaculikova, L., Kozusnikova, A., Ritz, M., \& Simha Martynkova, G. (2016). Thermal expansion behaviour of granites. Journal of Thermal Analysis and Calorimetry, 123(2), 1555-1561.

Poon, C.-S., Azhar, S., Anson, M., \& Wong, Y.-L. (2001). Comparison of the strength and durability performance of normal- and high-strength pozzolanic concretes at elevated temperatures. Cement and Concrete Research, 31(9), 1291-1300.

Rodriguez-Navarro, C., Ruiz-Agudo, E., Luque, A., RodriguezNavarro, A. B., \& Ortega-Huertas, M. (2009). Thermal decomposition of calcite: Mechanisms of formation and textural evolution of $\mathrm{CaO}$ nanocrystals. American Mineralogist, 94, 578-593.

Sakr, K., \& El-Hakim, E. (2005). Effect of high temperature or fire on heavy weight concrete properties. Cement and Concrete Research, 35(3), 590-596.

Savva, A., Manita, P., \& Sideris, K. K. (2005). Influence of elevated temperatures on the mechanical properties of blended cement concretes prepared with limestone and siliceous aggregates. Cement \& Concrete Composites, 27(2), 239-248.

Uygunoğlu, T., \& Topçu İ. B. (2012). Effect of aggregate type on linear thermal expansion of self-consolidating concrete at elevated temperatures. Science and Engineering of Composite Materials, 19(3), 259.

Wenk, H. R., \& Bulakh, A. (2004). Minerals: Their constitution and origin. Cambridge: Cambridge University Press.

Yao, W., \& Zheng, X. (2007). Effect of mix proportion on coefficient of thermal expansion of concrete. Tongji Daxue Xuebao/Journal of Tongji University, 35(1), 77-81 + 87.

Zhang, W., Qian, H., Sun, Q., \& Chen, Y. (2015). Experimental study of the effect of high temperature on primary wave velocity and microstructure of limestone. Environmental Earth Sciences, 74(7), 5739-5748. 